\title{
Corrigendum: Narrative materiality and practice: A study of born-free negotiation of periphery and centre
}

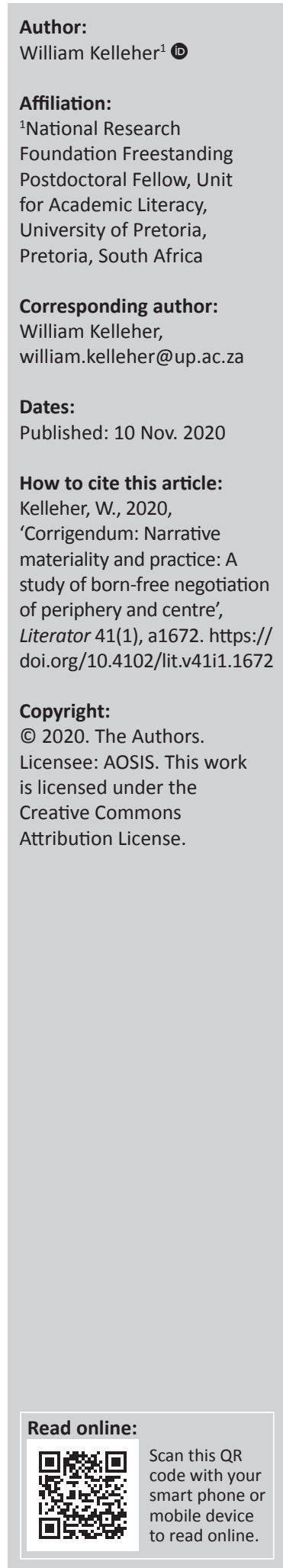

In the version of this article initially published, Kelleher, W., 2019, 'Narrative materiality and practice: A study of born-free negotiation of periphery and centre', Literator 40(1), a1573. https:/ / doi.org/10.4102/lit.v40i1.1573, the fact that the article draws on the author's PhD thesis was omitted. The acknowledgement is hereby updated as follows:

This article is partially based on the author's thesis for the degree of Doctor of Philosophy in the Department of Linguistics, School of Literature, Language and Media, University of the Witwatersrand, South Africa, with supervisor Prof. Tommaso Milani, received January 2018, available here: https://hdl. handle.net/10539/25897.

This correction does not alter the study's findings of significance or overall interpretation of the study's results. The author apologises for any inconvenience caused. 


\section{Narrative materiality and practice: A study of born-free negotiation of periphery and centre}

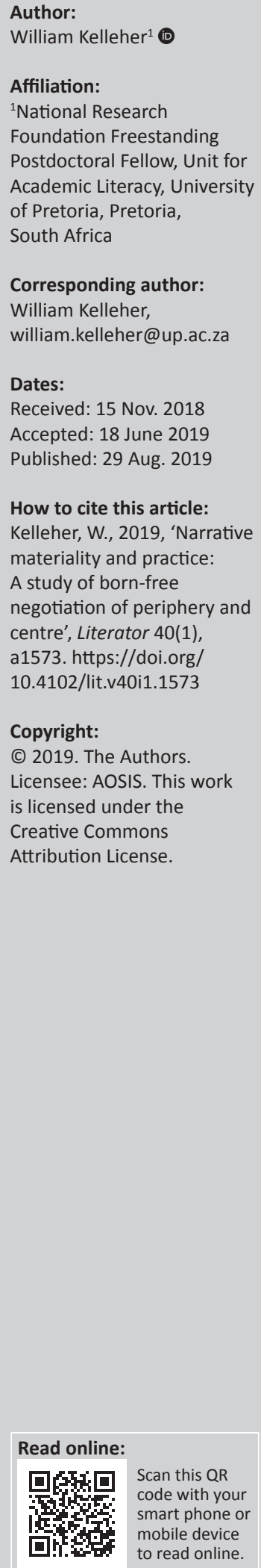

This article explores a small story narrative, the community of practice and the orientations of a group of 'born-free' participants as these interact with the material discourses of the Gautrain station in the business district of Sandton in the Gauteng, South Africa. 'Born frees' are young people born after the end of Apartheid. They are of interest in social studies because of the enormous demographic, familial and educational changes they represent. The discussion of the article concerns, firstly, the genre of account, and the relation between story and trajectory. Trajectory and the spatial coordinates of the story are introduced to understand what Sandton and its material discourses represent for these participants. The Gautrain station is then approached through geosemiotics. Thirdly, the negotiation of social space implicit in the coconstruction of the small story is analysed through axes of intersubjectivity applied to participant orientation and narrativisation. Methodologically, this article follows a new narrative turn that sees narrative as practice. It seeks to introduce materiality to analysis. As storytelling, from this perspective, is embedded within physically co-present texts, signs and representations, the methodology was to map samples of participant talk against a site. This allowed participant stories, isolated using qualitative audio annotation, to be situated in the exact place of their telling, and for analysis to include artefacts of the semiotic landscape, which is to say textual or visual ensembles such as notices, posters and billboards that are displayed in urban public space and that represent a circulation of wider discourses.

Keywords: Born frees; narrative; small stories; community of practice; trajectory; geosemiotics; axes of intersubjectivity.

\section{Introduction}

The principal assertion of this article is that a move from periphery to centre, in this case from the townships around Pretoria where average familial income can be ZAR 4000.00 per month (US\$ 278.00) to a centric business district like Sandton, where an entry-level attorney can earn ZAR 50000.00 per month (US\$3500.00), involves a negotiation of practice and identity. This negotiation can be captured in the narratives, trajectories and interactions of participants as they interplay with what, following the material ethnography of Stroud and Mpendukana (2009), we could call material discourses. The study focuses on narrative, and on interactional narrative practice, because stories are fundamentally motivated constructions, a locus of significant identity work.

The participants whose story we will be looking at are 'born frees': students and youth who were born 'free' of Apartheid following the democratic transition of 1994. An investigation of youth, the dynamics of their insertion into civil society and the space of the institution is important. Not only does this shed light on the result of societal change in South Africa over the past decades, but it also illuminates the future of the country, its modernity, and what will be the values, practices and beliefs that will guide present generations. Indeed, where South Africa presents interest, as a case study, is in its 20-year-old recovery from the devastating social engineering of Apartheid, and the ways in which youth navigate the declivities between urban periphery and centre, between access and gatekeeping at tertiary education institutions and, indeed, between all of the other markers of cultural capital that distinguish, assign and betray.

Analysis will follow the small stories movement. De Fina and Georgakopoulou (2008) refer to small stories as a new narrative turn that centres on practice and on the co-construction of stories within a changing configuration of narrative research (Bamberg 2007). Conceptually, what is at issue is not only the referential content of a story and what it means for the teller or the listener, but also telling roles, orientations and alignments, and what telling accomplishes interactionally. This therefore sees storytelling as caught up in both local processes such as group constitution and maintenance, as in wider social processes and discourses. Here, the participant story we will 
be looking at is part of a movement from township school, to university, to internship at a Sandton law firm. It is a transition that operates at the level of these born-free participants' integration within a new community of practice, that of law student, which is site-specific. Their transition, in other words, is a material one as much as it is a biographic and socio-historic one.

The aims and objectives of this article are therefore to conduct a small story analysis of data collected with born-free participants, and to trace this against the materiality of a site.

\section{Research design, participants and analytic framework}

The data presented here are part of a wider, site-based, ethnography that explored the material aspects of narrative interaction. Specifically, the methodology relied on initial interviews with participants to establish their familial situation, language repertoires and socio-economic information. These initial interviews were complemented with outings by participants to investigate their relation to the materiality of the research site. These outings were recorded by the participants using $\mathrm{mp} 3$ recorders whose date and time stamps were synchronised with global positioning system (GPS) logs so as to be able to plot their physical trajectories using QGIS (https://www.qgis.org/en/site/ index.html). To this information were added the field notes of the site and photographs (also GPS localised) of the semiotic artefacts of the site. It is a methodology that could perhaps be termed 'geomapped linguistic ethnography'. In total, a corpus of 356 small stories was collected with 76 direct and 230 indirect participants in 111 locations.

The setting of this study is a place of finance and consumption, Sandton. It is an unusual site in the country, for the wealth that it concentrates, and the conditions of this concentration. Sandton is a district in the Gauteng, a second Central Business District (CBD), for Johannesburg, that hosts most major corporate head offices, capital markets, retail brand outlets, a huge array of office and retail space, and which is situated at an apex position with respect to other sites of gross value added (GVA) in Gauteng, such as Fourways or Centurion. The story that is presented here comes from two of the direct participants in the study and has been chosen because of the longitudinal nature of the research relationship with these participants ( 3 years) and because of the nature of their trajectories to Sandton. These trajectories are biographic, professional and also linguistic in nature, with passage from sites of language contact to Sandton, which has an overt monolingual English policy.

The townships of Hammanskraal and of Mamelodi, from where these participants originate, are spaces in which the dominant language is Sepitori, a regional contact form of Setswana and Sesotho sa Leboa that also sometimes contains elements of Afrikaans or English (see Ditsele \& Mann 2014). A township is an urban agglomeration. Technically speaking Sandton also straddles township lines, but in South Africa, the term is used to designate those predominantly informal, poorly serviced and deliberately isolated areas that were racially demarcated under the Group Areas Act and used as dormitories for the city centre. One study that is particularly illustrative of what townships represent is offered by Dlamini (2009) who poses the question of how one can be nostalgic of the conditions of one's growing up, while still recognising their rampant inequality.

The two participants who collected the data we will be looking at are law students at the University of Pretoria who will be affecting their internship in Sandton and volunteered for this research project as a way of reflecting on this upcoming move. Nono is a female student and Mohau is a male student. They are joined in the research outing by two other female students Rindzela and Afrika. During term time, they reside in the student neighbourhood of Hatfield, relying on National Student Financial Aid Scheme (NSFAS) ${ }^{1}$ loans and aids, in addition to bursaries, to finance their study and residential costs. They are engaged students, who have received their financing in light of the excellence of their school results and who are aware of their status and their nascent community of practice, and who think in a serious and sensitive way about the debates of their time, such as the need for free education (the \#FeesMustFall movement ${ }^{2}$ ). Their narrative interactions, discussed below, throw up the agency of this country's students. In this sense, our discussion can be read off against other studies into South African youth demographics, behaviour and trends (see Boyce 2010; Jacobs \& Payet 2013; Mattes 2012; Seekings 2013), and the marked pessimism of some of these studies (see especially KaneBerman 2015) with respect to structural determinism.

Concerning analysis, the principal analytic framework, as noted, comes from the small stories movement within narrative research that focuses on the interactional coconstruction of stories. This broad framework will be applied to the data in three ways. Firstly, there is the relation of story to participant biography and trajectory that will need to be explored. Apartheid was a project that superposed and engineered the spatial as well as the social and the material. Participant trajectories from township to Sandton can thus be approached spatially, through their sites and locations, which can be referred to as their coordinates. De Fina (2009b) notes that story coordinates may be understood in terms of their semiotisation, how they are selected, represented and endowed with indexical signification within narratives. Further, tellers use linguistic strategies to invest these coordinates and their stories with social and individual meaning as well as to index subject positions. These two processes of semiotisation and linguistic investment of meaning and position can, additionally, be understood with respect to certain kinds of narrative discourse.

1.NSFAS or the National Student Financial Aid Scheme is the governmental service that supports students' tertiary studies.

2.\#FeesMustFall was the hashtag for a series of student-led protests calling for fee reduction or annulment, and more inclusive support strategies in the tertiary education sector in South Africa from 2015. The movement is strongly aligned with decolonisation as this affects teaching, such as in language policy or admissions. 
Secondly, we need to return to the interactional coconstruction of participant data and to the nexus of practice which informs it. Scollon (2001) indicates that when exploring a nexus of practice, the focus must be on social action, to which is pertinent a consideration of habitus, positioning, shared meanings, mediational means and socio-historic movements. Geosemiotics (Scollon \& Scollon 2003) is a framework for investigating this nexus. Geosemiotics looks at signs, or textual or visual ensembles, in light of four cycles of meaning that are habitus, or social actor, interaction order, visual semiotics and place semiotics. Social actor and interaction order direct analysis towards the expression of cultural values and towards the norms governing interaction. Visual semiotics and place semiotics are concerned with unpicking the multimodal meaning of signs in public space. For instance, in the data that are discussed below, the articulation of corporate discourse in the space of the site, and the multimodal means that are employed, such as the represented participants, their gestures and the slogans that accompany them, can be seen to be closely linked to participant interactions. Together, multimodal artefacts form what is termed a semiotic landscape, in which discourse is given material expression in notices, billboards, posters and other objects displayed publicly.

Thirdly, and finally, a negotiation of periphery and centre can be analysed using Bucholtz and Hall's tactics of intersubjectivity (Bucholtz \& Hall 2004a, 2004b, 2005) which are composed of three axes: similarity or difference, genuineness or artifice and authority or delegitimacy. The first of these axes, similarity and difference, or adequation and distinction, addresses markedness, and the pursuit, or subversion of, 'socially recognised sameness' (Bucholtz \& Hall 2004b:383). Through marked forms of language, a speaker nears or distances him or herself from a category that is seen as either preferential or dispreferential. Genuineness and artifice, or authentication and denaturalisation, the second axis, critiques essentialist conceptions of identity and moves for an investigation of context, practice and performance. On the one hand, this implies studying 'the processes by which authenticity is claimed, imposed or perceived', and the, 'untruth, pretence, and imposture in identity positioning' (Bucholtz \& Hall 2004a:498). On the other hand, it involves how assumptions regarding the seamlessness of identity can be disrupted' (Bucholtz \& Hall 2005:601). The third axis of authorisation and illegitimation addresses ideology and institutional power and 'the ways in which identities are dismissed, censored, or simply ignored' (Bucholtz \& Hall 2005:603).

Before turning to an exploration of trajectory, semiotics of place and axes of intersubjectivity, it is necessary to emphasise that this is qualitative research, concerned not with prescribing generalisable predictions of behaviour but rather with uncovering possible, local, ethnographic interpretations. Further, no internal coherence is claimed for this analysis nor for the data. Bucholtz and Hall capture this contingency, situatedness and partialness of data in their framework for sociocultural linguistic approaches (Bucholtz \& Hall 2005).

\section{An account and its trajectory}

The discussion that follows concerns an account. Accounts are told to justify, mitigate or repair a participant's alignment, or in response to evaluative questions (De Fina 2009a:240). Accounts are a genre of small stories that are therefore very useful in exploring participant positioning and negotiation of social configurations such as those present in institutions and other spaces associated with top-down discourses. The focus of this section is on the trajectory, both physical and biographical, that the participants of this study have effected from the townships of Hammanskraal and Mamelodi to the University of Pretoria in Hatfield, and then to the centric business district of Sandton where they will be doing their internship as law students. The changing materialities of this trajectory can here be approached, following De Fina (2009b), in terms of the coordinates of this movement from periphery to centre. We will look first at the storied world of the account, before exploring the linguistic strategies of the storytelling world and then pertinent narrative discourses.

In Box 1, in the storied world, the cashier in Hatfield who issued the group's tickets is heard to mutter that there is a problem. In the storytelling world, the participants are prevented from leaving the Sandton station because one of their group, Rindzela, has a ticket that no longer has any money loaded on it. They approach the cashier at Sandton to explain their case and obtain a means of exiting the station. The cashier and Mohau refer to 'multiple' tickets in terms of the fact that the Gautrain tickets are electronic but issued on a pay-per-ride basis, which means that often, a passenger has more than one ticket, some of which may have money loaded, others of which may be empty.

Box 1 is transcribed with a simple notation (see De Fina \& Georgakopoulou 2015) where bold shows raised voice, pauses are marked with ellipses, arrows mark shifts in intonation and square brackets indicate overlap. Timings in round brackets indicate longer pauses between turns.

The account of the cashier in Hatfield is given at turn (2) by Rindzela, but then orientated to by Mohau, the male student at turn (9) and then again at turn (25) to explain a possible cause of the problem with the ticket. There is a negotiation of telling rights, because Mohau, as spokesperson for the group, takes up Rindzela's initial story. The sites and movement within this story can first be looked at in the orientation of the narrative the section where the teller situates the action (Labov 1972:364). This orientation concerns the cashier in the Hatfield Gautrain station near the University of Pretoria. The key coordinates are therefore Hatfield and Sandton, and, subjacent to these, the townships of Hammanskraal and Mamelodi. If we turn to Figure 1, which reproduces a map of Gauteng where darker grey indicates higher percentages of tertiary education, the exclusion of these townships from access to professionalising education is strikingly obvious. The higher concentrations of tertiary education achievement run in a corridor that runs obliquely from South East Pretoria (the node in the North) to North West Johannesburg. Given South Africa's history, this 
BOX 1: Transcript of Nono and Mohau at the Sandton Gautrain - 10h16-06 February 2016.

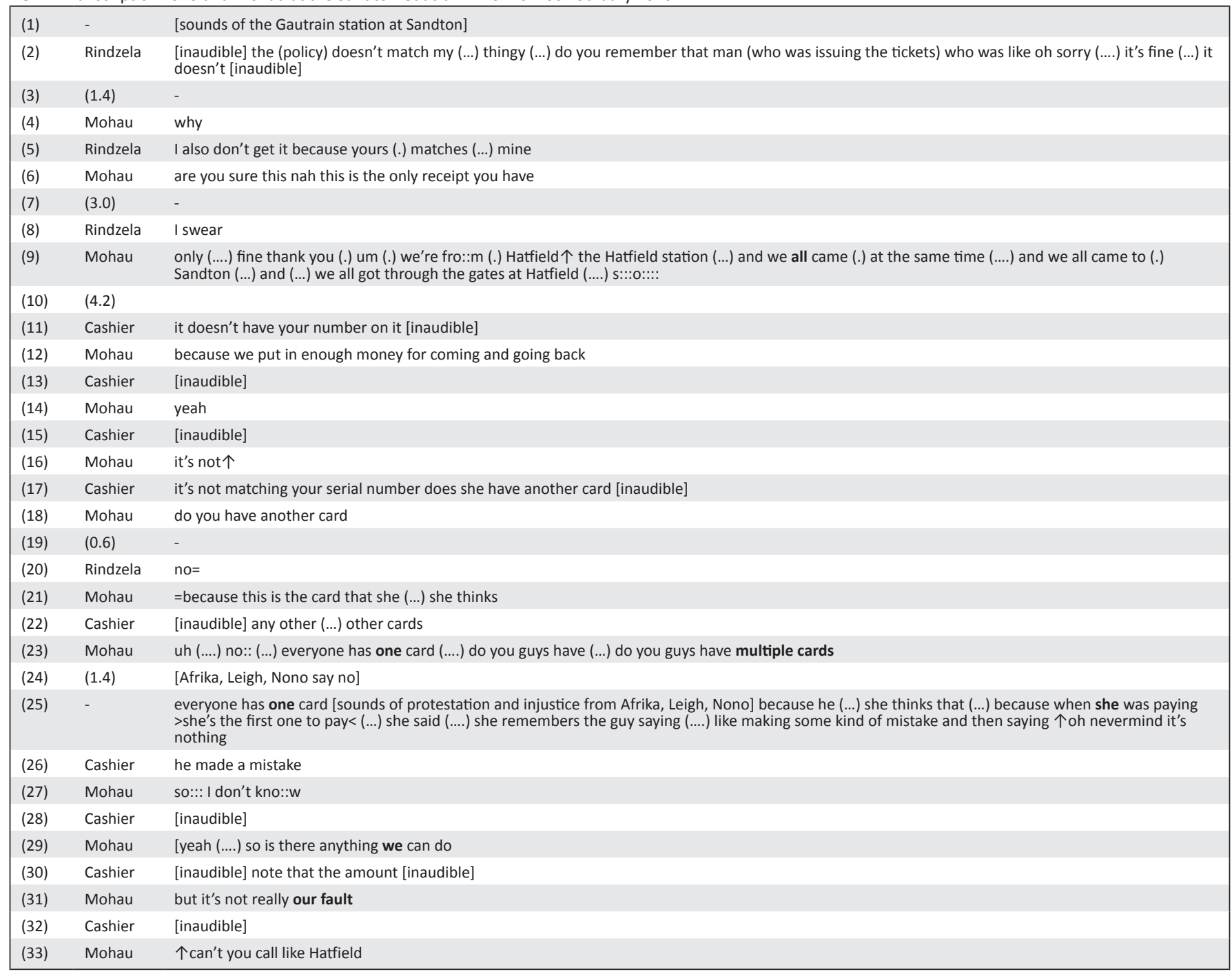

same corridor indicates socio-economic and cultural capital, and material conditions such as provision of services, formality of housing and quality of foodstuffs.

Within the trajectory of these students from township to university to Sandton, Hatfield is already a marker of aspiration and initial success. Coming from Hatfield means that one is a student, undergoing professionalisation, with prospects of employment and of financial independence. It should also be noted that the Hatfield station reproduces many of the institutional communication and discourses that one can find at the Sandton station. In this case, the voyage from Hatfield to Sandton is a change in place, but within a reticular discourse that englobes and channels identity and representation. This then adds to our understanding of the linguistic strategies that are used to index social meaning and subjective position (De Fina 2009b). The key linguistic strategy here must be the use of English, both between the members of the group and between them and the cashier. In addition, this is an English that is in a standard register and marked with full politeness formulas (see turn [9]). What is being indexed here, like the Hatfield station itself, is a form of negotiation, or navigation (see Vigh 2009), of social space, that already involves a move from periphery to centre.
This navigation takes place at a group as well as an individual level. These students are members of a community of practice, which is 'an aggregate of people who come together around mutual engagement in an endeavour. Ways of doing things, ways of talking, beliefs, values, power relations - in short, practices - emerge in the course of this mutual endeavour' (Eckert \& McConnell-Ginet 1992:464). In class, these students are learning about rights and due process, and it is this that is perhaps coming across at many points in the transcripts. They are both aware of, and orient actively to, their identity of students who are beginning to master a rhetoric and a discourse of power and institutional functioning. In communities of practice, stories are tied to group maintenance, because they are 'intertextually and dialogically linked, co-constructed spatiotemporal worlds of shared past, future, and hypothetical events' (Georgakopoulou 2005:165). Mohau and Nono's group is a nascent and provisional one, in that they have been thrown together by their studies. This research outing is an opportunity for a sharing and a co-construction of narrativised events. The account in Box 1, for instance, is told by Rindzela to mitigate the situation with her card. It is then retold by Mahau in a positioning gambit (see Bamberg 1997, 2008) to support the students' claim that the situation is not their fault (turn [31]). 


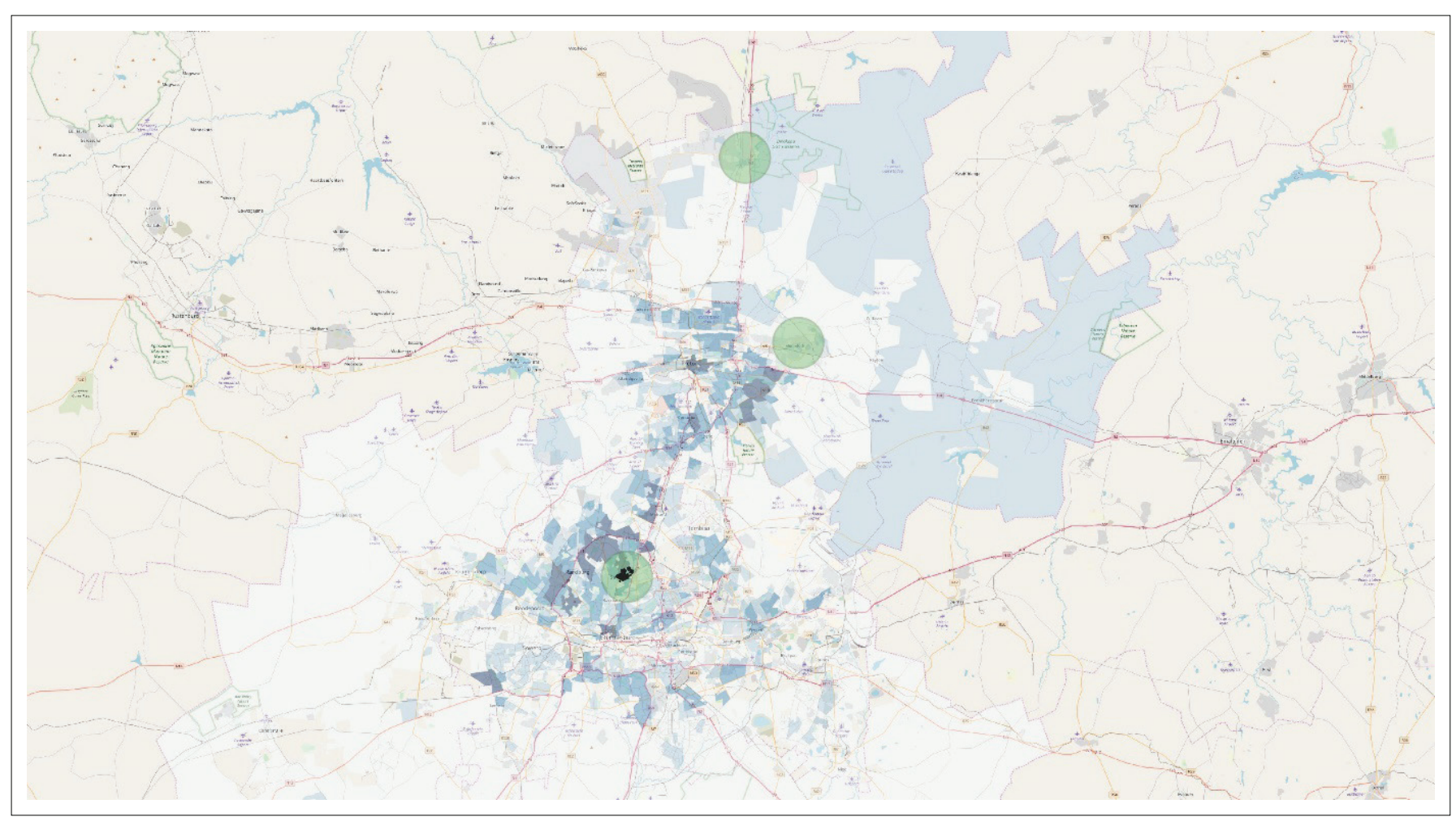

Source: Courtesy of William Kelleher.

Note: The map has three circles that show the locations of Sandton in the south west, Hammanskraal in the North and Mamelodi in the North East. Based on Statistics South Africa census of 2011 FIGURE 1: Map of the Gauteng where darker grey indicates higher percentages of completion of tertiary education.

To conclude, it is necessary to pose the question of the place that this story has in a certain narrative domain (De Fina 2009b:112). In the present case, one could explore stories of student success and overcoming of generational inequality following the end of Apartheid. These were very pertinent to state communication at the time of data collection and to the discourses that surround decoloniality and the \#feesmustfall movement. Space, and geographic movement, as shown graphically in Figure 1, is a signifier of aspiration in these discourses where the children of parents who grew up under Apartheid leave the periphery to enter an urbanised civil society. The participants, in the first section of the discussion, have been seen to represent narrative discourses such as these in their own biographies, and in the process to have negotiated storytelling rights, questions of gender and of appurtenance to a community of practice.

\section{Materiality and the Sandton Gautrain station}

In this next section, what is in question is the materiality of the Sandton Gautrain station, the nexus of practice that it shapes and constrains through its architecture and the artefacts of its semiotic landscape. We noted above that geosemiotics (Scollon \& Scollon 2003) is a means of analysing the social actors, interactions and semiotic artefacts that are pertinent to this site. To operationalise a geosemiotic framework, it is necessary to give stories physicality, a location. In the previous section, we looked at this in terms of trajectory; here, we will be looking at the site itself. Figure 2 is a close-up of the map shown in Figure 1. The dark star indicates the location of the account given in Box 1 , at the Gautrain station, with respect to the building footprint of Sandton Central as a whole. Localisation of storied interaction is not new; Sacks (1986), for instance, was concerned to situate both the events that gave rise to a story and the conditions of its telling. However, what changes here is the ability to pinpoint this for both participant and researcher, and for the researcher to be able to come back to the site, take notes and photographs and explore the nexus of practice.

The Gautrain station has the primary task of directing and distinguishing pedestrian traffic from the subterranean railway to the ground-level exit. One can think here about Thurlow and Jaworski's (2017) study of airport space. It does this through a series of juxtaposed escalators bolted up against a central vertical shaft. The general outlay is white veneer against brutalist concrete. Constructed by a French company, Bouygues, it bears similarities to the Train Grande Vitesse network in France. The high price of a ticket [approximately ZAR 80.00 (US\$ 6.00) single fare from Pretoria to Sandton) makes this train almost triple the price of a joint taxi ride, and reserves this mode of transport for the Gauteng's middle- and high-income commuter. However, the Sandton stop is also on the way to downtown Johannesburg and in the trains, though not at the station, there is a more heterogeneous social composition. The confines of the station, and its verticality, reinforce the sensation of a tight haptic space and a lack of time. Gautrains run infrequently, sometimes only twice an hour, and therefore, commuters are generally aware of time wastage. The configuration of the haptic space also advantages institutional advertisers, who dispose billboards that are almost inescapably 


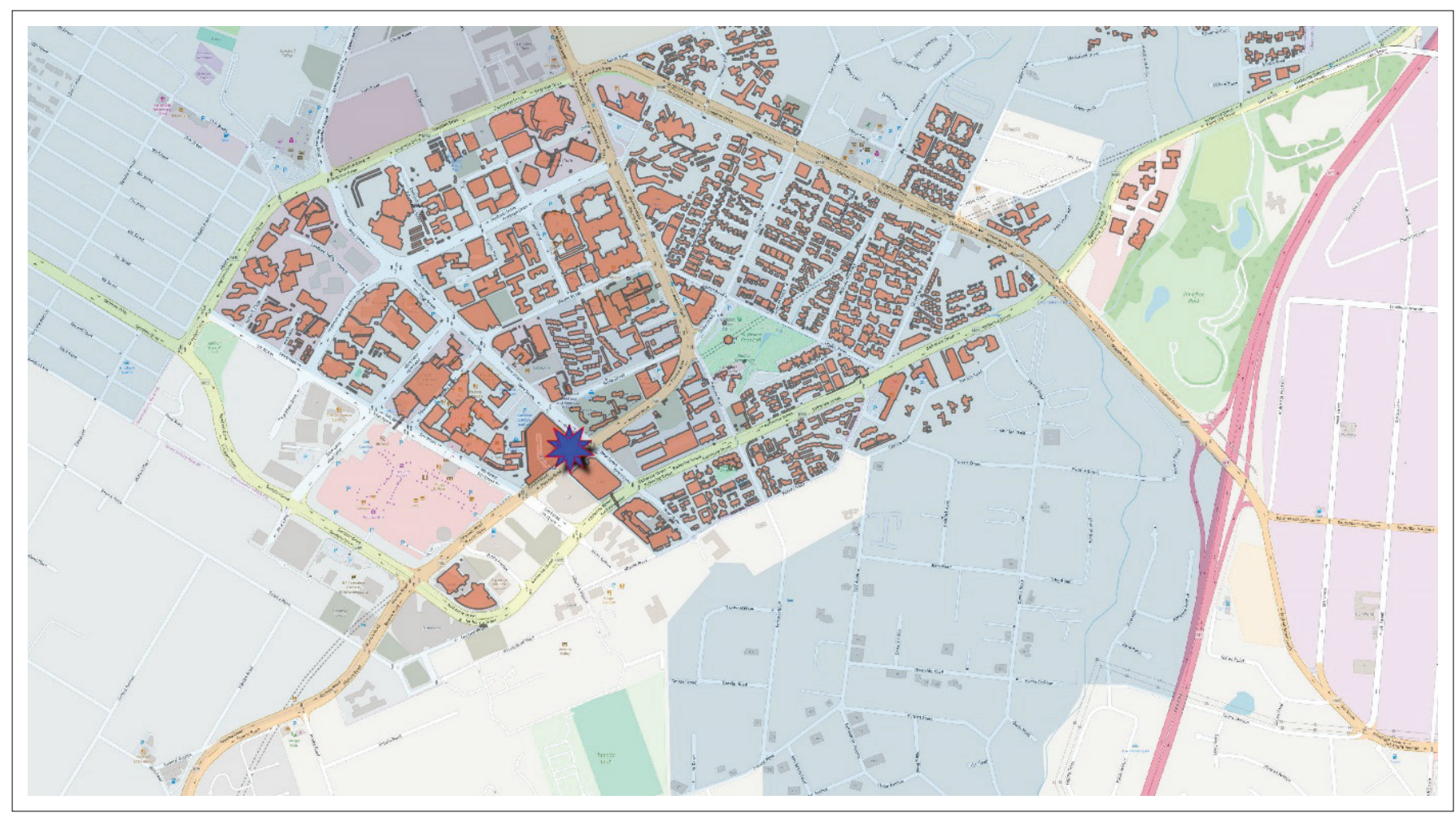

Source: Courtesy of William Kelleher.

Note: The mapping of Sandton against achievement of tertiary education is what accounts for the shading of the image and indicates that Sandton is situated in a zone of high tertiary educational achievement.

FIGURE 2: Close-up of location of Box 1 against the building footprint of Sandton Central.

visible. One of these billboards, photographed at the time of data collection, is given in Figure 3.

This artefact shows the awareness by institutional advertisers of the haptic and social space of the station. The represented participant is cool and smiling with eyes downturned to his right. This gaze contrasts with the interactional order of the billboard's location, and sets up a vector to indicate something acquired real (see Kress \& Van Leeuwen 1996). The colours of the billboard follow this vector. The information relative to Vodacom, the telephony operator, is in red, on the left, in the 'given' space of the billboard. The represented participant is on the right, in grey and white, in the 'new'. The overt message directly concerns the needs of commuters and indicates the joint project by Gautrain and Vodacom to provide telephony coverage in the Gautrain stations. That the represented participant should be young, black, dynamic and dressed for a good office job, and that he should be accompanied by a slogan that reads 'Change the Game', brings this advertisement into line with Nono and Mohau's community of practice. They, like him, wish to make their mark, take a stand and change the ways in which they can access professional employment. There is therefore a parallelism between the community of practice and the discourse of the artefact.

As Stroud and Mpendukana (2009) indicate, artefacts are moments in a circulation of discourses. Further aspects of this circulation that need to be taken into account are the institutional weight of advertisers, operators and station personnel. This can be appreciated in the fabrication and emplacement of the billboard, which is an example of topdown discourse that is isolated and protected from interaction. It would be impossible, for instance, to graffiti or write on this artefact both because of its remove from transiting pedestrians, but also because it is surveyed by up to 10 security personnel who move around on the mezzanine floor. The institutional weight is also found in the conditions of interaction that apply to the storytelling of Box 1. Mohau must speak to the cashier through bulletproof glass and under the gaze of a security guard that stands next to this window. In fact, one of the reasons that there is a negotiation of telling rights is that only one participant can be at the cashier's window at a time.

In the audio recording following Box 1, the station intercom can be heard repeating the following message, 'Hello dear customers, please remember to tag into and out of any Gautrain paid area, if you don't do this you will be charged for being there and you will become liable for prosecution'. It is in many ways against this security controlled, institutional, material space that the account in Box 1 is being told. Its objective, as noted, is to position these students with respect to institutional discourse. Their account of a problem experienced in Hatfield absolves the participants of responsibility for their ticket. The security-orientated aspect of discourses at the Sandton Gautrain modifies the parallels we have discussed between the participants' community of practice and the artefact of Figure 3. These participants are training to become attorneys and advocates, who will occupy 


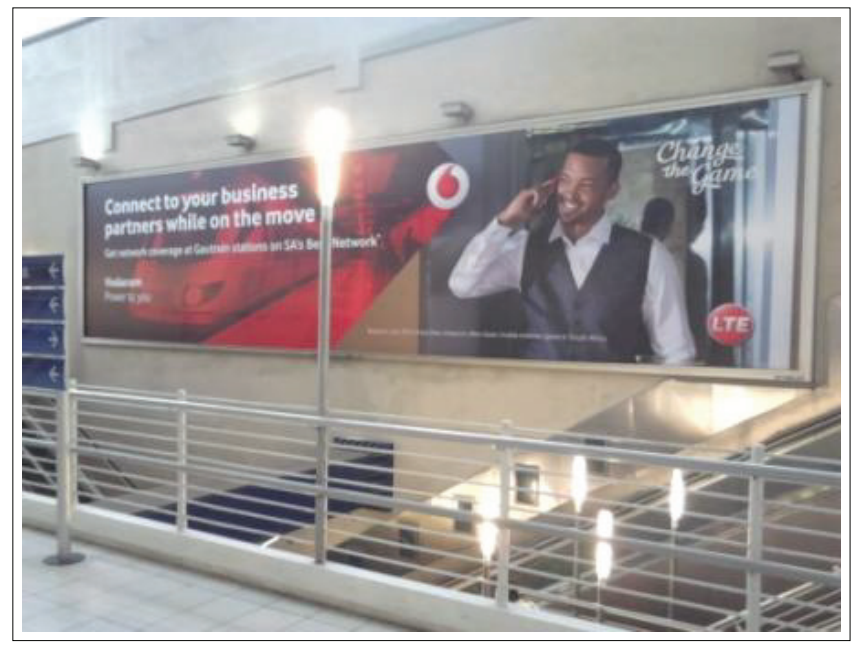

Source: Photo courtesy of William Kelleher.

Note: The advert concerns a new long-term evolution wireless brand for Vodacom, a primary South African telephony provider. The brand slogan in the top right reads 'Change the Game'. The copy reads, 'Connect to your business partners while on the move / Get network coverage at Gautrain stations on SA's [South Africa's] Best Network / Vodacom / Power to you'

FIGURE 3: Artefact of the semiotic and discursive environment at the Gautrain station, Sandton.

a specific place in the professional landscape of Sandton. They will become the mouthpieces of corporate actors before the courts and other instances of South Africa's neoliberal and hierarchised society. They will be on the side of security measures, not against them. But to explore the complexity of their negotiation of these material discourses, we must turn to their evaluation of the events of Box 1 and their orientation to the conditions of its telling.

\section{Negotiation of centre: Axes of intersubjectivity}

Just as the group is about to admit defeat, align with the cashier and pay the penalty necessary to leave the Gautrain station, Nono sees that, in fact, Rindzela did have another prepaid ticket in her bag. The account of Box 1 reveals itself as an interactional gambit. The talk that follows is transcribed in Box 2.

Box 2 serves as evaluation both of the story told by Mohau to the cashier, and also of the preceding situation concerning Rindzela's ticket. The different members of the group orient to the events in different ways. We can frame analysis of these orientations according to the axes of intersubjectivity proposed by Bucholtz and Hall (2004a, 2004b, 2005): similarity or difference, genuineness or artifice and authority or deligitimacy. A first point to note is that this orientation is framed explicitly in terms of their community of practice by Afrika and Mohau at turns (19) and (20). This can be interpreted in different ways. On the one hand, it is a marker of 'sameness' in that the reasons for the cohesion of the group are clearly emphasised. It can also be analysed as a bid for legitimacy, or authorisation. As lawyers, the space, and materiality, of Sandton, as discussed in the previous sections, accords much more with their biographic trajectory. However, finally, there is also a respect in which these students are not yet lawyers. They still need to pass their final exams, be admitted to articles and be registered. To what extent therefore do the interactions of Boxes 1 and 2 serve as a rupture, or a denaturalisation, of this nascent identity?

The power of the institution to delegitimate can be seen in the fact that the cashier is absolutely not convinced by the students' arguments, nor by their account. She refuses to call Hatfield and insists that they pay the amount necessary to leave the station. This institutional attitude is picked up in Box 2 in Nono's turn (5), 'we almost got killed for this'. In a similar way, Mohau himself admits (turn [12]) that he could have 'goofed up' his performance as a defender of rights. However, he is quick to emphasise the genuineness of his behaviour with reference to management generally (turn [24]) and to this event in particular (turn [20]). Rindzela's orientation to the events is more complex. On the one hand, she is concerned to emphasise that her mistake was a genuine one, the repetition of 'I swear' at turn (3). On the other hand, she makes light of the institutional consequences of the mixup with laughter at turns (6) and (8) and a sardonic characterisation of her acts at turn (40) where she 'calms down' the personnel. She is also responsible for another episode of confusion when she throws away a ticket that had an expired ZAR 70.00 (US\$ 5.00) on it (turns [30]-[45]).

Turning back to the materiality of the station and its artefacts, the orientations of these students as transcribed in Box 2 again nuance the parallels between discourse and narrative interaction. Their stories and evaluations do match both the 'Change the Game' slogan of the billboard and the institutional weight of the discourses that circulate, but this matching takes place within their community of practice that here gains in solidity and cohesion. The events of Boxes 1 and 2 are in the process of becoming shared stories, stories that will be shared by the group and inform subsequent interpretative viewpoints (see Georgakopoulou 2006:127) in the context of future retellings and transpositions of this story. Interpretative viewpoints concern how a participant uses narrativised prior knowledge to construct his or her subsequent interactions. This narrativisation can be seen in the fact that the speakers of Box 2 are characterising themselves and in so doing changing their footing in the situation of interaction. It is the case in Afrika's assertion that she felt like a lawyer (turn [19]), but it is also the reason for her attribution of direct speech to the personnel in turn (22). Use of direct speech is an indication of employment of the insertion of events into story lines. She introduces the direct speech at (22) with the quotative 'like', 'like< $-h h h$ (...) like bad customers'. Mohau also characterises his resistance to the situation in a similar way at turn (20) using 'like' as both focaliser and quotative, 'and I was like he::ll (...) no:: (...) [laughter] we we doing this (...) like'.

This evaluation of experience through narrativisation brings out another level at which the transcripts of the participants can be read against the material discourses of the environing space. In characterisation, if not completely in the situation of 
BOX 2: Transcript of Nono and Mohau at the Sandton Gautrain - 10h21 - 06 February 2016.

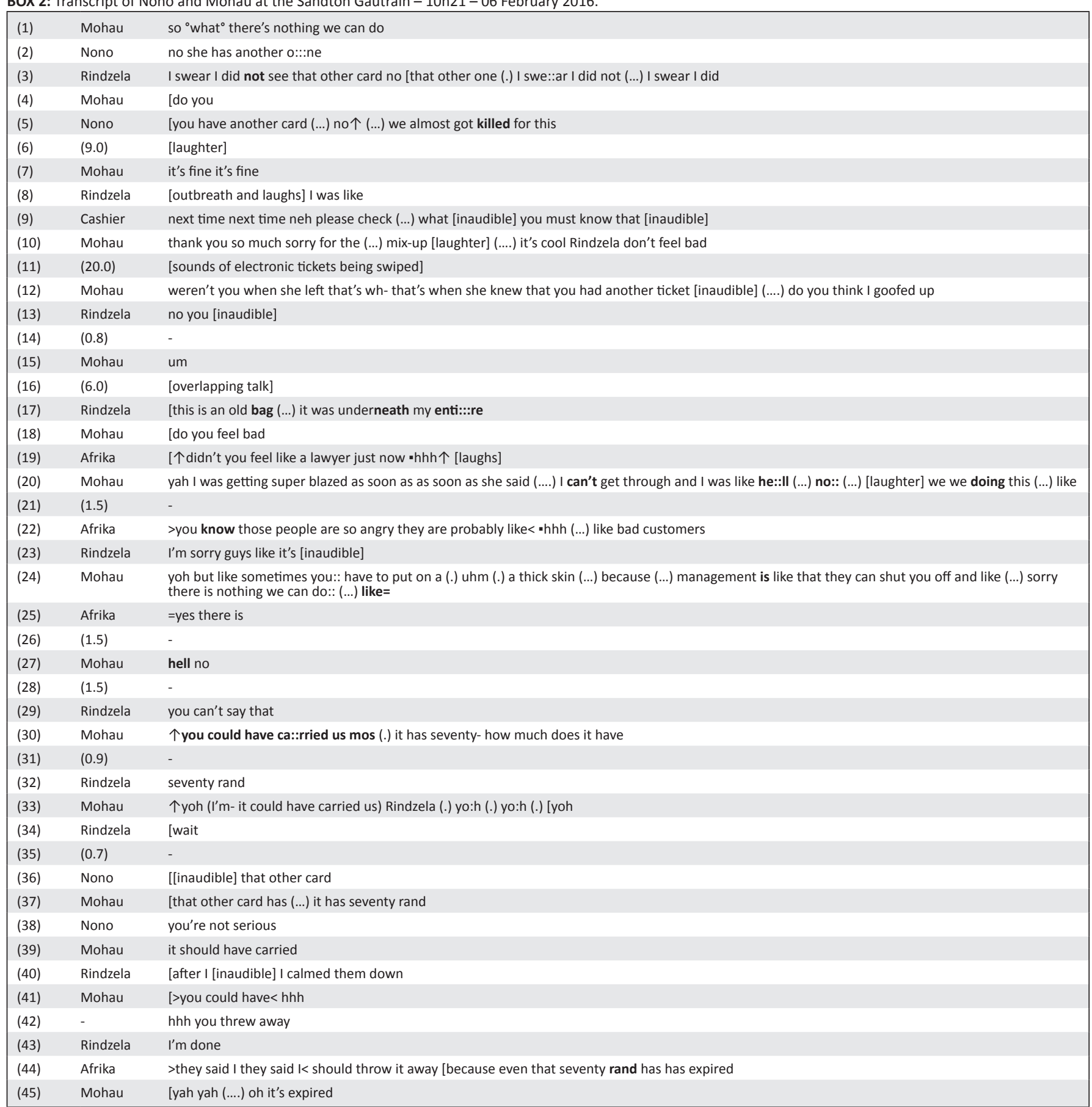

interaction, Mohau does 'change the game'. Navigation of practice and discourse occurs at both the level of the storied world and at the level of the situation of interaction with changes in footing by participants as they near or distance themselves through narrativisation strategies.

\section{Conclusion}

This article has investigated the negotiation of periphery and centre of a group of born-free university students. The central focus has been on how this negotiation could be studied in the narrative interactions of participants, and through the interplay between these and material discourses. The structuring axis for the investigation has been the emphasis, brought by the small stories approach to narrative, on telling as practice and on the responsiveness of the storied world to the contours of the storytelling world. This emphasis was translated, firstly, in a concern to map the trajectory of participant stories both geographically and biographically. Secondly, it prompted an exploration of the material discourses pertinent to the situation of interaction. Finally, it led to a consideration of the identity work being accomplished by the participants.

By mapping participant stories, we have been able to better understand the coordinates of the account that the participants co-constructed and the indexicality of these 
coordinates. In exploring the material discourses of the site in which the story was told, we have been better able to appreciate the articulation of institutional discourses and the orientation of participants towards those discourses. In considering the identity work being accomplished by participants, we have seen how important narrativisation can be to community of practice. The discussion has highlighted the points of intersection of narrative research, geosemiotic analysis of artefacts of the semiotic landscape and the axes of intersubjectivity pertinent to interlocutor orientation and evaluation. The telling of stories, and the evaluation thereof, allows members of a group to navigate the discourses and practices implied by their changing position in social and material space.

\section{Acknowledgements}

Sincere thanks go to the participants to this research and to structures such as the Sandton City Mall, the Johannesburg Stock Exchange, the Sandton Convention Centre as well as Johannesburg City.

\section{Competing interests}

The author declares that he has no financial or personal relationships that may have inappropriately influenced him in writing this article.

\section{Author's contributions}

I am the sole author of this article.

\section{Ethical consideration}

Data were collected in the context of a doctoral project with the University of the Witwatersrand (ethics clearance number H15/07/23).

\section{Funding}

The research presented was funded through Oppenheimer Memorial Trust and National Research Foundation Freestanding Doctoral awards. Currently, the author benefits from a National Research Foundation Freestanding Postdoctoral Fellowship.

\section{Data availability statement}

Data sharing is not applicable to this article as no new data were created or analysed in this study.

\section{Disclaimer}

The views and opinions expressed in this article are those of the authors and do not necessarily reflect the official policy or position of any affiliated agency of the authors.

\section{References}

Bamberg, M., 1997, 'Positioning between structure and performance', Journal of Narrative and Life History 7(1-4), 335-342. https://doi.org/10.1075/jnlh.7.42pos Bamberg, M. (ed.), 2007, Narrative - State of the art, John Benjamins, Amsterdam/ Philadelphia.

Bamberg, M., 2008, 'Twice-told tales: Small story analysis and the process of identity formation' in T. Sugiman, K.J. Gergen, W. Wagner \& Y Yamada (eds.), Meaning in action: Constructions, narratives, and representations, pp. 183-222, Springer, Japan.

Boyce, G., 2010, 'Youth voices in South Africa: Echoes in the age of hope', in B. Roberts, M.W. Kivilu \& Y.D. Davids (eds.), South African social attitudes: The 2nd Report, pp. 87-104, HSRC Press, Pretoria.

Bucholtz, M. \& Hall, K., 2004a, 'Theorising identity in language and sexuality research' Language in Society 33(4), 469-515. https://doi.org/10.1017/\$004740450044021

Bucholtz, M. \& Hall, K., 2004b, 'Language and identity', in A. Duranti (ed.), A companion to linguistic anthropology, pp. 369-394, Blackwell, Oxford.

Bucholtz, M. \& Hall, K., 2005, 'Identity and interaction: A sociocultural linguistic approach', Discourse Studies 7(4-5), 585-614. https://doi.org/10.1177/ 1461445605054407

De Fina, A., 2009a, 'Narratives in interview - The case of accounts (for an interactional approach to narrative genres)', Narrative Inquiry 19(2), 233-258. https://doi. org/10.1075/ni.19.2.03def

De Fina, A., 2009b, 'From space to spatialization in narrative studies', in J. Collins, S. Slembrouck \& M. Baynham (eds.), Globalization and language in contact: Scale, migration and communicative practices, pp. 109-129, Continuum, London and New York.

De Fina, A. \& Georgakopoulou, A., 2008, 'Analysing narratives as practices', Qualitative Research 8(3), 379-387. https://doi.org/10.1177/1468794106093634

De Fina, A. \& Georgakopoulou, A. (eds.), 2015, The handbook of narrative analysis, Wiley Blackwell, Oxford.

Ditsele, T. \& Mann, C.C., 2014, 'Language contact in African urban settings: The case of Sepitori in Tshwane', South African Journal of African Languages 34(2), 150-165. https://doi.org/10.1080/02572117.2014.997052

Dlamini, J., 2009, Native Nostalgia, Jacana, Johannesburg.

Eckert, P. \& McConnell-Ginet, S., 1992, 'Think practically and look locally: Language and gender as community based practice', Annual Review of Anthropology 1992(21), 461-90. https://doi.org/10.1146/annurev.an.21.100192.002333

Georgakopoulou, A., 2005, 'Styling men and masculinities: Interactional and identity aspects at work', Language in Society 34(2), 163-184. https://doi.org/10.1017/ S0047404505050074

Georgakopoulou, A., 2006, 'Thinking big with small stories in narrative and identity analysis', Narrative Inquiry 16(1), 122-130. https://doi.org/10.1075/ni.16.1.16geo

Jacobs, M. \& Payet, J-P., 2013, 'Les mondes juvéniles d’une génération née libre: Dynamiques de déracialisation chez les adolescents des ex-townships scolarisés dans l'Afrique du Sud (Johannesburg) post-Apartheid', Presses de Sciences Po (P.F.N.S.P.) (66), 3-20. https://doi.org/10.3917/autr.066.0003

Kane-Berman, J., 2015, Born free but still in chains: South Africa's first post-apartheid generation, South African Institute of Race Relations, Johannesburg.

Kress, G. \& Van Leeuwen, T., 2006, Reading images: The grammar of visual design, Routledge, London and New York.

Labov, W., 1972, Language in the inner city, University of Pennsylvania Press, Pennsylvania, PA.

Mattes, R., 2012, 'The "born frees": The prospects for generational change in postapartheid South Africa', Australian Journal of Political Science 47(1), 133-153. https://doi.org/10.1080/10361146.2011.643166

Sacks, H., (1986), 'Some considerations of a story told in ordinary conversations', Poetics 15, 127-138. https://doi.org/10.1016/0304-422X(86)90036-7

Scollon, R., 2001, Mediated discourse [the nexus of practice], Routledge, London and New York.

Scollon, R. \& Scollon, S.W., 2003, Discourses in place: Language in the material world, Routledge, London and New York.

Seekings, J., 2013, 'The social and political implications of demographic change in post-Apartheid South Africa', The ANNALS of the American Academy of Political and Social Science 652(1), 70-86. https://doi.org/10.1177/0002716213508265

Statistics South Africa (StatsSA), 2011, Census, Statistics South Africa, Pretoria.

Stroud, C. \& Mpendukana, S., 2009, 'Towards a material ethnography of linguistic landscape: Multilingualism, mobility and space in a South African township', Journal of Sociolinguistics 13(3), 363-386. https://doi.org/10.1111/j.1467-9841.2009.00410x

Thurlow, C. \& Jaworski, A., 2017, 'Word-things and thing-words: the transmodal production of privilege and status', in J.R. Cavanaugh \& S. Shankar (eds.), Language and materiality: ethnographic and theoretical explorations, pp. 185-203, Cambridge University Press, Cambridge.

Vigh, H., 2009, 'Motion squared: A second look at the concept of social navigation', Anthropological theory 9(4), 419-438. https://doi.org/10.1177/1463499609356044 